Readers who found these articles interesting may also like to read these papers that can be found in recent issues of our sister publications, Seminars in Thoracic and Cardiovascular Surgery and Operative Techniques in Thoracic and Cardiovascular Surgery!

\title{
THORACIC
}

\section{Thoracic Oncology}

Seminars

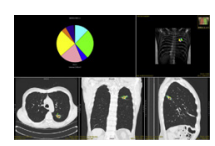

NEWS AND VIEWS: Computer-Aided Nodule Assessment and Risk Yield Risk Management of Adenocarcinoma: The Future of Imaging? Finbar Foley. Semin Thoracic Surg 2016; 28:120-126.

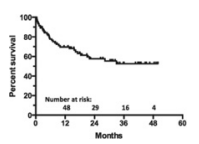

ORIGINAL SUBMISSION: Robotic Esophagectomy for Cancer: Early Results and Lessons Learned. Robert

J. Cerfolio. Semin Thoracic Surg 2016; 28:160-169.

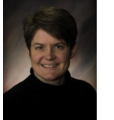

Editorial Commentary: Improving Quality: When Surgeons Take the Bit Between the Teeth, Patients Win! Katie S. Nason. Semin Thoracic Surg 2016: 28:170-171.

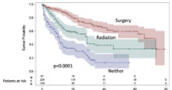

ORIGINAL SUBMISSION: Second Primary Lung Cancers Demonstrate Better Survival with Surgery than Radiation. Emanuela Taioli. Semin Thoracic Surg 2016; 28:195-200.

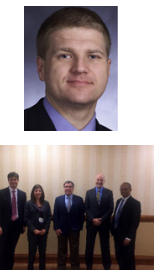

Editorial Commentary: Surgery is the Optimum Local Therapeutic Modality for Second Primary Lung Cancer. Jeffrey L. Port. Semin Thoracic Surg 2016; 28:201-202.

DISCUSSIONS IN CARDIOTHORACIC TREATMENT AND CARE: The Next Generation of Mesothelioma

Surgeons. Harvey I. Pass. Semin Thoracic Surg 2016; 28: 203-220.

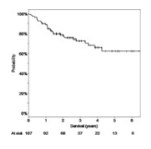

ORIGINAL SUBMISSION: The 3-Hole Minimally Invasive Esophagectomy: A Safe Procedure Following Neoadjuvant Chemotherapy and $\therefore \therefore \div \quad$ Radiation.

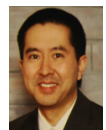

Editorial Commentary: With Minimally Invasive Esophagecomty, Thoracic Surgeons Must Avoid Falling Into the Same Trap Again. Ng Thomas. Semin Thoracic Surg 2015; 27:216-217.

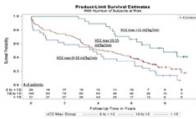

ORIGINAL SUBMISSION: Maximal Oxygen Uptake Risk Predictor of NSCLC Resection with Comorbid Emphysema: Lessons from NETT. Ian Makey. Semin Thoracic Surg 2015; 27:225-224.

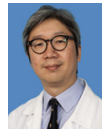

Editorial Commentary: How Can the NETT Provide Guidance in Risk Stratification for Patients with Severe Emphysema and Early Stage NSCLC? Michael Hsin. Semin Thoracic Surg 2015; 27:232-233.

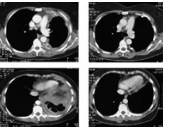

STATE OF THE ART: Induction Therapy for Mesothelioma. Isabelle Schmitt-Opitz. Semin Thoracic Surg 2015; 27:240-249.

\section{Other Thoracic Surgical Papers}

\section{Seminars}
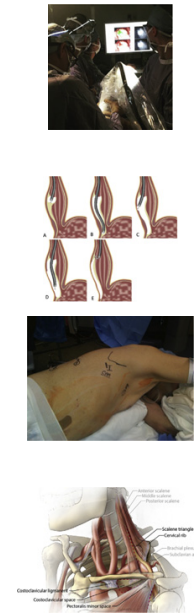
136. 147-150. Surg 2016; 28:151-157.
STATE OF THE ART: Novel Methods of Intraoperative Localization and Margin Assessment of Pulmonary Nodules. Jane Keating. Semin Thoracic Surg 2016; 28:127-

STATE OF THE ART: The State of the Art in Per-Oral Endoscopic Myotomy. Stavros N. Stavropoulous.

Semin Thoracic Surg 2016; 28:137-146.

CURRENT READINGS: The 5 Most Important Recent Publications Regarding Robotic Esophageal Surgery. Zane Hammoud. Semin Thoracic Surg 2016; 28:

ORIGINAL SUBMISSION: Vascular Thoracic Outlet Syndrome. Mohamad Anas Hussain. Semin Thoracic
Editorial Commentary: Searching for Lights at Dusk. Scott Reznik. Semin Thoracic Surg 2016; 28:158-159.

ORIGINAL SUBMISSION: Effect of Esophagus Position on Surgical Difficulty and Postoperative Morbidities After Thoracoscopic Esophagectomy. Naoya Yoshida. Semin Thoracic Surg 2016; 28:172-179.

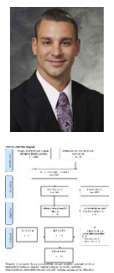

Editorial Commentary: Digging Deeper to Understand the Challenges of Minimally Invasive Esophagectomy. Ryan A. Macke. Semin Thoracic Surg 2016; 28:180-181.

ORIGINAL SUBMISSION: The Use of Robotic-Assisted Thoracic Surgery for Lung Resection: A Comprehensive Systematic Review. John Agzarian Semin Thoracic Surg 2016; 28:182-192. 


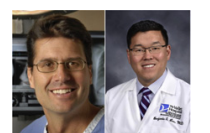

Editorial Commentary: Robotic Assisted Thoracic Surgery Lobectomy vs. Video Assisted Thoracic Surgery Lobectomy: Is a Randomized Trial Really Necessary? Robert J. Korst. Semin Thoracic Surg 2016; 28:193-194.
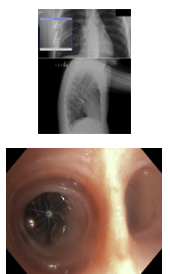

NEWS AND VIEWS: Recent and Future Developments in Chest Wall Reconstruction. Calvin S.H. Ng. Semin Thoracic Surg 2015; 27:234-239.

ORIGINAL SUBMISSION: Endobronchial Treatment of Bronchopleural Fistulas by Using Intrabronchial Valve System: A Case Series. Eitan Podgaetz. Semin Thoracic Surg 2015; 27:218-222.

Editorial Commentary: One-Way Valves to the Rescue or Bronchopleural Fistulae. Eric J. Seeley. Semin Thoracic Surg 2015; 27:223-224.
Op Techs

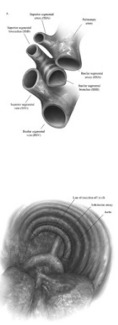

80

Surgical Management of Esophageal Perforation. Manu Sancheti. Oper Tech Thorac Cardiovasc Surg 2015; 20: 234-250.

Endoscopic Techniques for the Management of Esophageal Perforation. Shanda H. Blackmon. Oper Tech Thorac Cardiovasc Surg 2015; 20:251-278.

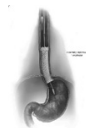

Video-Assisted Thoracoscopic Segmentectomy of Lower Lobe: Superior and Basilar

Segmentectomy. Nathaly P. Llore. Oper Tech Thorac Cardiovasc Surg 2015; 20:162-175.

Robotic First Rib Resection. Eric Strother. Oper Tech Thorac Cardiovasc Surg 2015; 20:176-188.

\section{ACQUIRED}

\section{Coronary Artery Disease}

Seminars

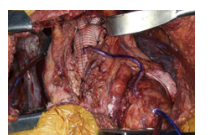

ORIGINAL SUBMISSION: Open Aortic Arch

Reconstruction After Coronary Artery Bypass

Surgery: Worth the Effort? Eduard Quintana. Semin

Thoracic Surg 2016; 28:26-35.

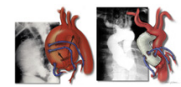

Editorial Commentary: Risky Business or Acceptable Risk? Open Arch Repair After Coronary Artery Bypass Surgery. Joseph S. Coselli. Semin Thoracic Surg 2016; 28: 36-37.
Original Submissions: Micromorphology of

Skeletonized and Pedicled Internal Thoracic and Radial Arteries. Sergey Mamchur. Semin Thoracic Surg 2015; 27:115-120.

Editorial Commentary: Harvesting Arterial Grafts: Barebones or More. Faisal G. Bakaeen. Semin Thoracic Surg

\section{Valvular Heart Disease}

Seminars

ORIGINAL SUBMISSION: Should Moderate-to-Severe
Tricuspid Regurgitation be Repaired During
Reoperative Left-Sided Valve Procedures? Igor
Gosev. Semin Thoracic Surg 2016; 28:38-45.
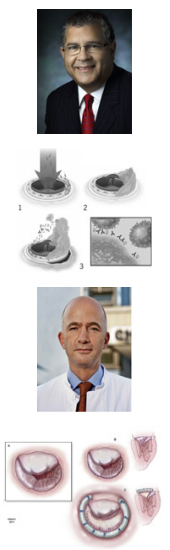

Editorial Commentary: To Fix or Not to Fix? That is the Question. Kenton J. Zehr. Semin Thoracic Surg 2016;28:46-47.

ORIGINAL SUBMISSION: Current Hypotheses in Cardiac Surgery: Biofilm in Infective Endocarditis. Haytham Elgharably. Semin Thoracic Surg 2016; 28:56-59.

Editorial Commentary: Treatment of Infective Endocarditis - Are We On the Right Track? Hans-Joachim Schafers. Semin Thoracic Surg 2016; 28:60-61.

ORIGINALSUBMISSION: Posterior Leaflet Detachment, Augmentation, and Reconstruction for Treatment of Functional Mitral Valve Regurgitation. Rakesh M. Suri. Semin Thoracic Surg 2015; 27:91-94. 2015; 27:121-122.
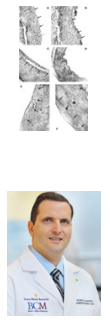
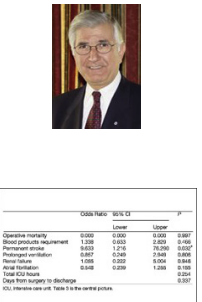

Editorial Commentary: Patch Augmentation of Mitral Valve Leaflet in Ischemic Mitral Regurgitation. Tirone E. David. Semin Thoracic Surg 2015; 27:95-96.

ORIGINAL SUBMISSION: Elevated Stroke Risk Associated with Femoral Artery Cannulation During Mitral Valve Surgery. Kareem Bedeir. Semin Thoracic Surg 2015; 27:97-103.

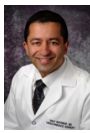

Editorial Commentary: Are We Going Backwards or Forwards in Minimally Invasive Mitral Valve Surgery? Three Eras of Perfusion Strategy. Vinay Badhwar. Semin Thoracic Surg 2015; 27:104-105.

CURRENT READINGS: Selection of Valve Prostheses. Cristian Rosu. Semin Thoracic Surg 2015; 27:152-158.

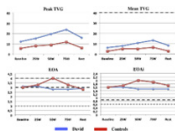

ORIGINAL SUBMISSION: Long-Term Hemodynamic Performance of the Aortic Valve Late After David I: An Echocardiographic Study. Antonino S. Rubino. Semin Thoracic Surg 2015; 27:257-263. 


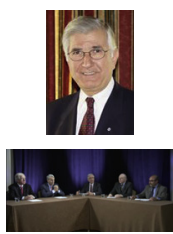

Editorial Commentary: Back to David I. Tirone E. David Semin Thoracic Surg 2015; 27:264-265.

DISCUSSION IN CARDIOTHORACIC TREATMENT AND CARE: Aortic Valve/Root Repair. Tirone David. Semin Thoracic E Surg 2015; 27:271-287.

Op Techs

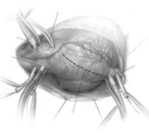

Biatrial Transseptal Approach for Combined Mitral Valve and Tricuspid Valve Operations. Mahim

Malik. Oper Tech Thorac Cardiovasc Surg 2015; 20:2-16.

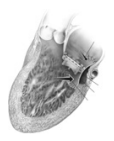

Mitral Valve Replacement for Infective Endocarditis with Annular Abscess: Annular Reconstruction. Gregory J. Bittle. Oper Tech Thorac Cardiovasc Surg 2015 20:17-30.

Mitral Annuloplasty Using A Biodegradable Annuloplasty Ring. Sanjay Cherian. Oper Tech Thorac Cardiovasc Surg 2015; 20:124-134

Myxomatous Mitral Valve Repair: Loop Neochord Technique. Robert C. Neely. Oper Tech Thorac Cardiovasc Surg 2015; 20:106-123.

\section{Aortic Disease}

\section{Seminars}

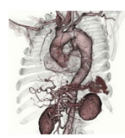

ORIGINAL SUBMISSION: Outcomes of Open Surgical Repair for Type B Dissecting Aortic Aneurysm with Alternative Methods in the Endovascular Stent Era. Mitsumasa Hata. Semin Thoracic Surg 2015; 27:106-112.

Editorial Commentary: It is Difficult to Compare Apples and Oranges: Acute and Chronic Type B Aortic Dissections, Complicated and Uncomplicated, are Different and Should be Treated as Such. Ourania Preventza. Semin Thoracic Surg 2015; 27:113-114.

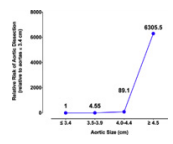

NEWS AND VIEWS: Treatment of Thoracic Aortic Aneurysm: Role of Earlier Intervention. Bulat A.

Ziganshin. Semin Thoracic Surg 2015; 27;135-143.
Op Techs

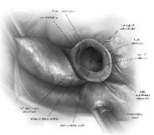

Aortic Root Enlargement During Aortic Valve Replacement: Nicks and Manouguian Techniques. Kendra J Grub. Oper Tech Thorac Cardiovasc Surg 2015; 20 206-218.

The Konno-Rastan Procedure for Anterior Aortic Annular Enlargement. Mark E. Roeser. Oper Tech Thorac Cardiovasc Surg 2015; 20:219-233.

\section{CONGENITAL}

\section{Seminars}
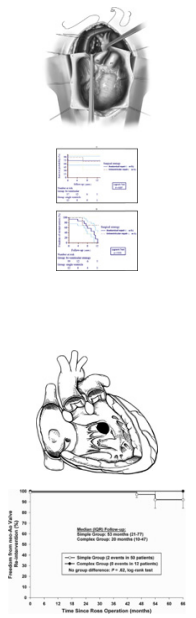

NEWS AND VIEWS: Advances in Surgical Treatment of Congenital Airway Disease. William S. Ragalie. Semin Thoracic Surg 2016; 28:62-68.

ORIGINAL SUBMISSION: Double-Outlet Right Ventricle With Noncommitted Ventricular Septal Defect and 2 Adequate Ventricles: Is Anatomical Repair Advantageous? Olivier Villemain. Semin Thoracic Surg 2016; 28:69-77.

Editorial Commentary: Double Outlet Right Ventricle: Where are we Now? Carl L. Backer. Semin Thoracic Surg 2016; 28:79-80.

ORIGINAL SUBMISSION: Outcomes and Short-Term Follow-Up in Complex Ross Operations in Pediatric Patients Undergoing Damus-Kaye-Stansel

Takedown. Christopher W. Baird. Semin Thoracic Surg 2016; 28:81-89.

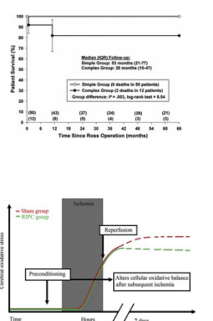

Editorial Commentary: Biventricular Repair With a Ross Procedure After a Norwood Procedure: A Big Operation for a Big Problem. Kirk R. Kanter. Semin Thoracic Surg 2016; 28:90-91.

ORIGINAL SUBMISSION: Remote Ischemic Preconditioning Reduces Cerebral Oxidative Stress Following Hypothermic Circulatory Arrest in a Porcine Model. Oiva Arvola. Semin Thoracic Surg 2016; 28:92-102.

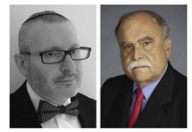

Editorial Commentary: Remote Ischemic Preconditioning: A Quest for Reason. Edward Gologorsky. Semin Thoracic Surg 2016; 28:103-104.

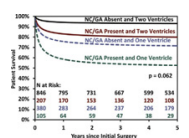

ORIGINAL SUBMISSION: The Effect of Noncardiac and Genetic Abnormalities on Outcomes Following Neonatal Congenital Heart Surgery. Bahaaldin Alsoufi. Semin Thoracic Surg 2016; 28:105-114. 


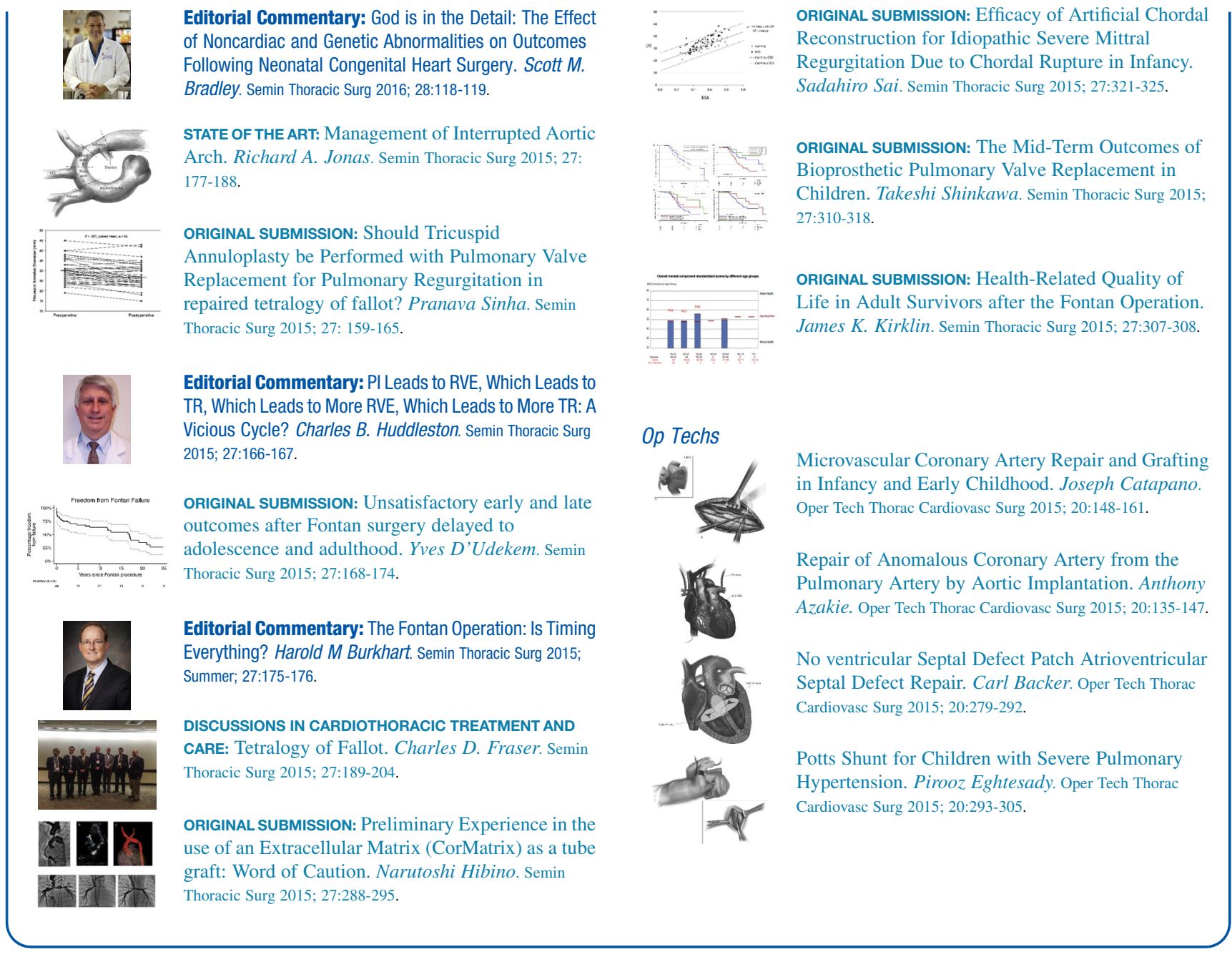

\section{TRANSPLANTATION AND MECHANICAL CIRCULATORY SUPPORT}

\section{Seminars}
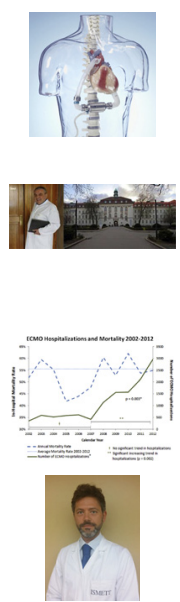

ORIGINALSUBMISSION: Rotary Blood Pumps as LongTerm Mechanical Circulatory Support: A Review of a 15-Year Berlin Experience. Roland Hetzer. Semin Thoracic Surg 2016; 28:12-23.

Editorial Commentary: Insights and Perspectives into Durable Mechanical Circulatory Support with Continuous Flow Technology from the Deutsches Herzzentrum Berlin. Francis D. Pagani. Semin Thoracic Surg 2016; 28:24-25.

ORIGINAL SUBMISSION: Trends in U.S. Extracorporeal Membrane Oxygenation Use and Outcomes: 2002-2012. Fenton H McCarthy. Semin Thoracic Surg 2015; 27:81-88.

Editorial Commentary: Is it Worth it to Increase the Use of Extracorporeal Membrane Oxygenation? Marco Morsolini. Semin Thoracic Surg 2015; 27:89-90.

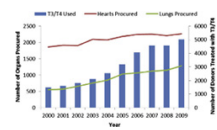

ORIGINAL SUBMISSION: Increased Procurement of Thoracic Donor Organs After Thyroid Hormone Therapy. Dimitri Novitzky. Semin Thoracic Surg 2015; 27 123-132.

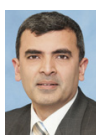

Editorial Commentary: Optimizing Donor Quality Via Hormonal Therapy: An Important Strategy to Increase Successful Placement of Thoracic Organs in End-Stage Patients. Syed M. Peer. Semin Thoracic Surg 2015; 27:133-134.

Op Techs

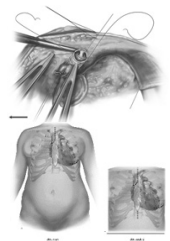

Median Sternotomy for Lung Transplantation. John Dark. Oper Tech Thorac Cardiovasc Surg 2015; 20:87-103.

Less Invasive Techniques for Left Ventricular Assist Device Implantation. Scott C. Silvestry. Oper Tech Thorac Cardiovasc Surg 2015; 20:189-203. 


\section{EVOLVING TECHNOLOGY AND BASIC SCIENCE}

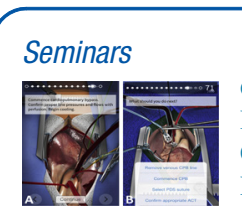

ORIGINAL SUBMISSION: Creation and Global

Deployment of a Mobile, Application-Based

Cognitive Simulator for Cardiac Surgical

Procedures. Zachary E. Brewer. Semin Thoracic Surg

2016; 28:1-9.

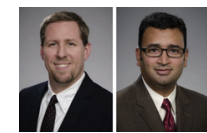

Editorial Commentary: "And" is Better Than "Or".

Joshua L. Hermsen. Semin Thoracic Surg 2016; 28:10-11.

\section{EDUCATION}

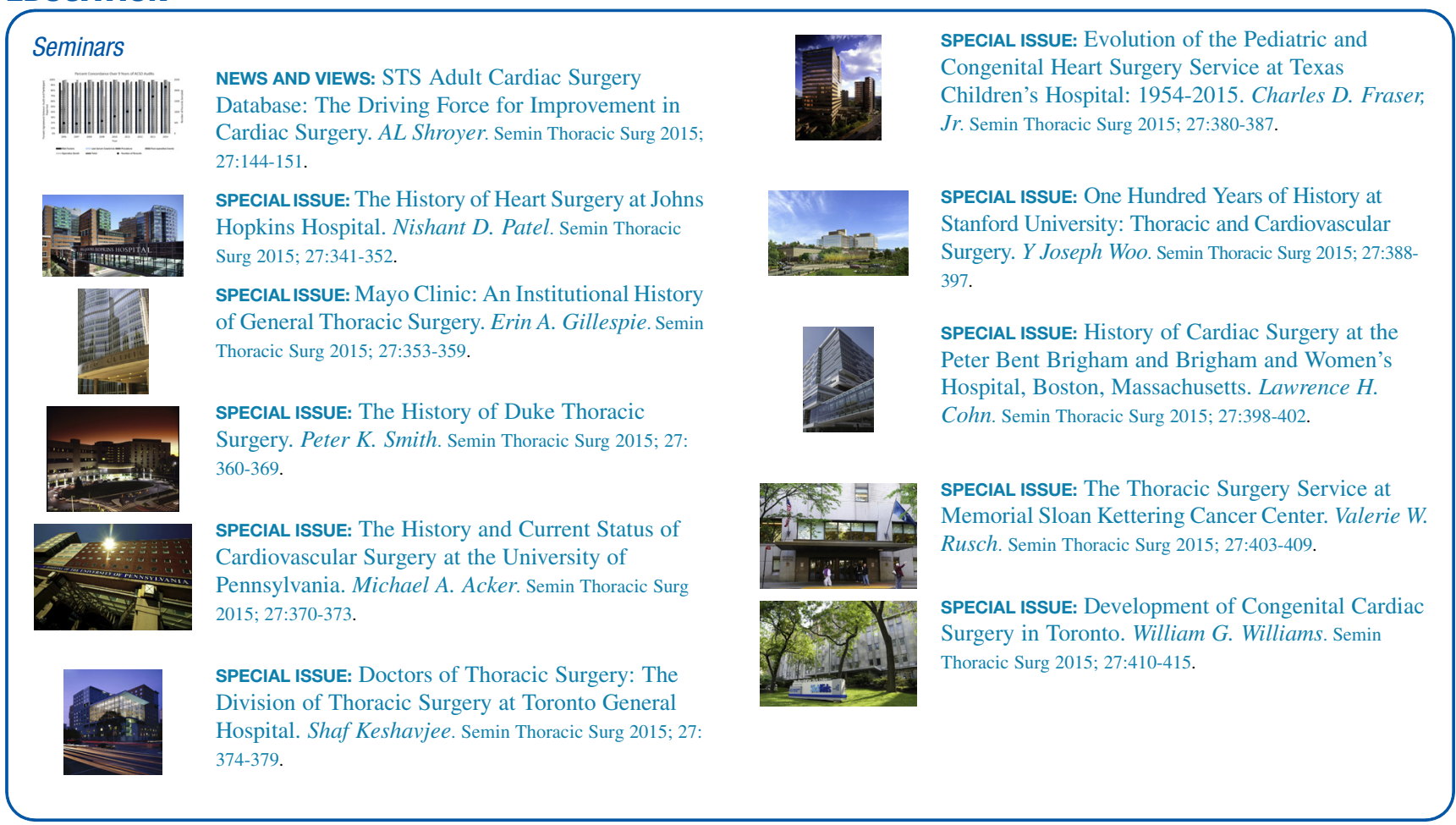

